\title{
A Pre-Prototype 2015 Social Accounting Matrix (SAM) for Myanmar
}

Dirk van Seventer, ${ }^{1}$ Finn Tarp, ${ }^{1,2}$ Nyo Nyo San,${ }^{3}$ and Khin Ohnmar Myint Thein ${ }^{3}$

March 2019 
Abstract: This paper documents the compilation of a Pre-Prototype 2015 Social Accounting Matrix for Myanmar and provides an overview of key economic structural features of this emerging economy in a challenging process of transition. We built this Social Accounting Matrix using National Accounts and Supply and Use Table data as well as Balance of Payment data for the 2014-15 fiscal year together with Government Budget Statistics from the 2017 Statistical Yearbook. It provides a detailed representation of the Myanmar economy and identifies 43 activities and 43 commodities. We disaggregated labour by education attainment level and household income and expenditure by per capita expenditure quintiles for both urban and rural areas and farm and non-farm categories. The Social Accounting Matrix features government, investment, and foreign accounts and is a key database for conducting economy-wide impact assessments to strengthen the evidence underlying policy interventions.

Keywords: social accounting matrix, national accounts, supply table, use table, Myanmar JEL classification: C63, E01, E16, P44

Acknowledgements: This research is part of the project 'Towards inclusive development in Myanmar' supported by Danida and implemented in collaboration between UNU-WIDER, the Central Statistical Organization (CSO) of the Ministry of Planning and Finance of Myanmar, and the Development Economics Research Group (DERG) of the University of Copenhagen. We warmly acknowledge the active collaboration with the whole CSO SAM building team.

${ }^{1}$ UNU-WIDER, Helsinki, Finland; ${ }^{2}$ University of Copenhagen, Copenhagen, Denmark, corresponding author: finn.tarp@econ.ku.dk; ${ }^{3}$ Central Statistical Organization, Nay Pyi Taw, Myanmar.

This study has been prepared within the UNU-WIDER project on 'Towards inclusive development in Myanmar'.

Copyright (C) UNU-WIDER 2019

Information and requests: publications@wider.unu.edu

ISSN 1798-7237 ISBN 978-92-9256-655-5 https://doi.org/10.35188/UNU-WIDER/2019/655-5

Typescript prepared by Lesley Ellen.

The United Nations University World Institute for Development Economics Research provides economic analysis and policy advice with the aim of promoting sustainable and equitable development. The Institute began operations in 1985 in Helsinki, Finland, as the first research and training centre of the United Nations University. Today it is a unique blend of think tank, research institute, and UN agency — providing a range of services from policy advice to governments as well as freely available original research.

The Institute is funded through income from an endowment fund with additional contributions to its work programme from Finland, Sweden, and the United Kingdom as well as earmarked contributions for specific projects from a variety of donors.

Katajanokanlaituri 6 B, 00160 Helsinki, Finland

The views expressed in this paper are those of the author(s), and do not necessarily reflect the views of the Institute or the United Nations University, nor the programme/project donors. 


\section{Table of contents}

1 Introduction 1

2 General structure of SAMs 1

3 Constructing the SAM 4

4 Finalizing the SAM 9

5 Employment 9

6 The structure of the Myanmar economy 10

7 Data issues 16

8 Way forward 17

References $\quad 17$

\section{List of acronyms}

$\begin{array}{ll}\text { ADB } & \text { Asian Development Bank } \\ \text { CSO } & \text { Central Statistical Organization } \\ \text { GDP } & \text { Gross Domestic Product } \\ \text { LFS } & \text { Labour Force Survey } \\ \text { MLCS } & \text { Myanmar Living Conditions Survey (2017) } \\ \text { MoPF } & \text { Ministry of Planning and Finance } \\ \text { MPLCS } & \text { Myanmar Poverty and Living Conditions Survey (2015) } \\ \text { PD } & \text { Planning Department } \\ \text { SAM } & \text { Social Accounting Matrix } \\ \text { SUT } & \text { Supply and Use Table }\end{array}$


This study outlines the construction of a Pre-Prototype 2015 Social Accounting Matrix (SAM) for Myanmar and provides an overview of key economic structural features of this emerging economy in a challenging process of transition. A SAM is a consistent data framework that captures data and information contained in national income accounts and industry and product accounts, as well as the monetary flows between the institutions of the economy. Since the SAM is a square accounting framework, total receipts (row totals) must equal total payments (column totals) for each matching account reported in the SAM. We collected the required data from various sources. It was therefore necessary to make a careful and time-consuming effort to compile the data in a coherent manner and make it consistent. This process was valuable since it helped with identifying inconsistencies among the original statistical sources. For example, there are invariably differences between the incomes and expenditures reported in household surveys and national accounts. SAMs are economy-wide databases used in conjunction with analytical techniques to strengthen the evidence underlying policy formulation processes and decision-making.

We used three main sources of data for the Pre-Prototype 2015 Myanmar SAM developed in this document. First, we used a 2016 report containing 2015 Myanmar National Accounts data, a Supply and Use Table and associated Balance of Payment data (Ministry of Planning and Finance 2016) compiled by the Asian Development Bank (ADB) and the Myanmar Planning Department (PD) of the Ministry of Planning and Finance (hereafter referred as the 'SUT document'). Second, we obtained the 2015 Government Budget Statistics from the 2017 Statistical Year Book (CSO 2017). Third, we used the 2015 Myanmar Poverty and Living Conditions Survey (MPLCS) (MoPF 2017) for the breakdown of labour and households.

The SAM provides a detailed representation of the Myanmar economy, identifying 43 activities and 43 commodities. It disaggregates labour by education attainment level and household income and expenditures by per capita expenditure quintiles for urban and rural areas and engagement in farming activities. The SAM identifies government, investment, and foreign accounts.

After this introduction, Section 2 reviews the general structure of SAMs. Section 3 describes the data sources used to construct the SAM, while we discuss the finalization of the detailed SAM accounts in Section 4. In Section 5, we describe an attempt to estimate matching employment data while Section 6 briefly describes selected aspects of the Myanmar economic structure through the lens of the SAM. Section 7 reports on key data issues noted during the compilation process, highlighting the need for further work on this SAM, addressed in the concluding Section 8.

\section{General structure of SAMs}

A SAM is an economy-wide accounting framework that usually represents the real economy of a single country ${ }^{1}$ reported as a square matrix with each account represented by a row and column. Each cell shows the payment from the account shown in the column heading to the account shown in the row heading - the incomes of an account appear along its row, its expenditures down its column. The underlying principle of double-entry accounting requires that for each account in the

\footnotetext{
${ }^{1}$ For general discussions of SAMs and SAM-based modelling, see Pyatt and Round (1985), Pyatt (1988), Arndt et al. (2000), Tarp et al. (2002), and Breisinger et al. (2009).
} 
SAM, total revenue (row total) equals total expenditure (column total). Table 1 shows an aggregate SAM (with written explanations instead of numbers) with reference to Myanmar-specific data.

The SAM makes a distinction between 'activities' (the entities that carry out production) and 'commodities' (representing markets for goods and non-factor services). SAM flows are valued at producers' prices in the activity accounts and at market prices (including indirect commodity taxes and transactions costs) in the commodity accounts. The commodities consist of output produced by local activities (which are either exported or sold domestically) and imports.

Payments by activities shown as entries down the columns in the SAM go to commodity accounts (comprising locally produced and imported goods and non-factor services, at market prices) for intermediate demand, and factors of production (value added comprising operating surplus and compensation of employees, land and/or livestock). The commodity accounts make payments (shown again as columns) to domestic activities, the rest of the world, and various tax accounts (for domestic and import taxes). This treatment allows for the data to model imports as perfect or imperfect substitutes vis-à-vis domestic production.

Government consists of a core government account and different tax collection accounts, one for each tax type identified in the data. In the SAM, direct payments between the enterprises, households, government, and the rest of the world reflect transfers as reported in the National Accounts, Government Budget, and Balance of Payment statistics. As mentioned earlier, in the case of Myanmar, we draw on Government Budget Statistics as published in the 2017 Statistical Yearbook (CSO 2017) and Balance of Payment statistics from the SUT document.

The SAM contains a number of factors of production, which earn incomes from their use in the production process, and then pay their incomes to enterprises, households, government, and the rest of the world. Government taxes indirect capital earnings and enterprise profits according to the average corporate tax rates, and the SAM also reflects the repatriation of some profits abroad. The remaining capital earnings, together with labour earnings, appear as payments to households. Households use their incomes to pay taxes, make transfers, save, and consume a combination of domestically produced and imported commodities. 
Table 1: The basic structure of a 2015 SAM for Myanmar

\begin{tabular}{|c|c|c|c|c|c|c|c|c|c|c|c|c|}
\hline & Row number & Activities & Commodities & Factors & Enterprises & Households & Government & Taxes & Investment & $\begin{array}{c}\text { Change in } \\
\text { stocks }\end{array}$ & $\begin{array}{c}\text { Rest of the } \\
\text { world (RoW) }\end{array}$ & Total \\
\hline $\begin{array}{c}\text { Column serial } \\
\text { number }\end{array}$ & & $1(43)^{*}$ & $2(43)$ & $3(11)$ & $4(1)$ & $5(20)$ & $6(1)$ & $7(5)$ & $8(1)$ & $9(1)$ & $10(1)$ & \\
\hline Activities & 1 & & $\begin{array}{c}\text { Marketed } \\
\text { output }\end{array}$ & & & & & & & & & $\begin{array}{l}\text { Activity } \\
\text { income }\end{array}$ \\
\hline Commodities & 2 & $\begin{array}{l}\text { Intermediate } \\
\text { inputs }\end{array}$ & $\begin{array}{l}\text { Transaction } \\
\text { costs }\end{array}$ & & & \begin{tabular}{c|} 
Marketed \\
consumption of \\
households
\end{tabular} & $\begin{array}{c}\text { Marketed } \\
\text { consumption of } \\
\text { households }\end{array}$ & & Investment & $\begin{array}{c}\text { Change in } \\
\text { stocks }\end{array}$ & Exports & Total demand \\
\hline Factors & 3 & Value added & & & & & & & & & $\begin{array}{c}\text { Remittances } \\
\text { received by } \\
\text { Myanmar } \\
\text { factors from } \\
\text { RoW }\end{array}$ & $\begin{array}{c}\text { Factor } \\
\text { earnings }\end{array}$ \\
\hline Enterprises & 4 & & & \begin{tabular}{|l|} 
Factor income \\
to enterprises
\end{tabular} & & & $\begin{array}{l}\text { Transfers to } \\
\text { enterprises } \\
\end{array}$ & & & & & $\begin{array}{c}\text { Enterprises } \\
\text { earnings }\end{array}$ \\
\hline Households & 5 & & & \begin{tabular}{|l|} 
Factor income \\
to households
\end{tabular} & \begin{tabular}{|c|} 
Indirect capital \\
payments
\end{tabular} & & $\begin{array}{l}\text { Transfers to } \\
\text { households }\end{array}$ & & & & $\begin{array}{c}\text { Net foreign } \\
\text { remittances } \\
\text { received }\end{array}$ & $\begin{array}{l}\text { Household } \\
\text { income }\end{array}$ \\
\hline Government & 6 & & & & \begin{tabular}{|c|} 
Revenue from \\
state economic \\
enterprises \\
\end{tabular} & & & $\begin{array}{c}\text { Revenue from } \\
\text { taxes }\end{array}$ & & & \begin{tabular}{|c|} 
Net foreign \\
transfers to the \\
government \\
\end{tabular} & $\begin{array}{c}\text { Government } \\
\text { income }\end{array}$ \\
\hline Taxes & 7 & Activity taxes & Sales taxes & Factor taxes & \begin{tabular}{|c|} 
Corporate \\
income taxes \\
\end{tabular} & Personal taxes & & & & & & \begin{tabular}{|c|}
$\begin{array}{c}\text { Revenue from } \\
\text { taxes }\end{array}$ \\
\end{tabular} \\
\hline Savings & 8 & & & & $\begin{array}{c}\text { Enterprises } \\
\text { savings }\end{array}$ & $\begin{array}{c}\text { Household } \\
\text { savings }\end{array}$ & $\begin{array}{c}\text { Government } \\
\text { savings }\end{array}$ & & & & Foreign savings & Savings \\
\hline $\begin{array}{c}\text { Change in } \\
\text { stocks }\end{array}$ & 9 & & & & & & & & $\begin{array}{c}\text { Change in } \\
\text { stocks }\end{array}$ & & & $\begin{array}{c}\text { Change in } \\
\text { stocks }\end{array}$ \\
\hline $\begin{array}{l}\text { Rest of the } \\
\text { world }\end{array}$ & 10 & & Imports & \begin{tabular}{|c|} 
Gross \\
payments to \\
foreign owned \\
factors of \\
production \\
\end{tabular} & $\begin{array}{l}\text { Enterprise } \\
\text { payments to } \\
\text { Row }\end{array}$ & & \begin{tabular}{|c|} 
Government \\
Transfers to the \\
Row
\end{tabular} & & & & & $\begin{array}{l}\text { Foreign } \\
\text { exchange } \\
\text { outflow }\end{array}$ \\
\hline Total & & Gross output & Total supply & $\begin{array}{c}\text { Factor } \\
\text { expenditure }\end{array}$ & $\begin{array}{c}\text { Enterprise } \\
\text { expenditure }\end{array}$ & $\begin{array}{l}\text { Household } \\
\text { expenditure }\end{array}$ & $\begin{array}{l}\text { Government } \\
\text { expenditure }\end{array}$ & $\begin{array}{c}\text { Revenue from } \\
\text { taxes }\end{array}$ & Investment & $\begin{array}{l}\text { Change in } \\
\text { stock }\end{array}$ & $\begin{array}{l}\text { Foreign } \\
\text { exchange } \\
\text { inflow }\end{array}$ & \\
\hline
\end{tabular}

Source: Authors' compilation. 
The main challenge of building a SAM involves combining data from various sources into an internally coherent SAM framework. For Myanmar, we collected this information from the National Accounts, associated Balance of Payment data and a Supply and Use Table from the SUT document, as well as Government Budget Statistics from the 2017 Statistical Year Book (CSO 2017).

The SUT document's data components consist of Supply and Use Table data, National Accounts, and Balance of Payment data. They are internally consistent (barring some rounding differences). Given total savings, it is possible to derive domestic savings since foreign savings equal the negative of the current account on the Balance of Payment. The breakdown of domestic savings in government and non-government reflects that the budget surplus on the public sector's current account is available in the Government Budget Statistics from the 2017 Statistical Year Book (CSO 2017). The residual non-government domestic savings are broken down into enterprise and household savings. The latter is the balancing item of the household accounts, while enterprise savings make up the balancing item of the savings-investment account.

Put differently, a number of steps are involved in constructing the SAM. The first step in constructing the Myanmar SAM is compiling national accounts and other official data sources into a consistent Macro SAM framework, which we subsequently expand with detailed industries and products using a Supply and Use Table. We name this a SUTSAM. Households and the production factor labour appear in the SUTSAM as single accounts.

The second step in turn draws on survey information to disaggregate the labour and the household accounts. The breakdown of labour and household accounts makes use of the unpublished MPLCS by PD (2016), which we discuss in more detail in the next section.

The Macro SAM shown in Table 2 is an aggregation of the more detailed Micro SAM. The rest of this section explains how each Macro SAM entry is derived and disaggregated, and we discuss in turn each entry in the SAM. The notation for SAM entries is (row, column) and the values are in billions of Kyat $(\mathrm{MMK}){ }^{2}$ Product and industry classifications are available in Appendix $\mathrm{A}$ and a global set of all accounts in the SAM is included in Appendix B.

1 (Commodities, Activities)...MMK99,809 billion

Intermediate inputs. Available from the 2015 Use Table, Table 9, SUT document. The dimensions of disaggregation are 43 commodities $\mathrm{x} 43$ activities. The source of the disaggregation is the 2015 Use Table, Table 9, SUT document.

2 (Labour, Activities)...MMK17,486 billion

Wage earnings. Available from the 2015 Use Table, Table 9, SUT document. The

dimensions of disaggregation are 24 labour types (no-education illiterate/no-education literate/monastery/primary/secondary/tertiary education, and rural/urban and farm/nonfarm) x 43 activities. The source of the disaggregation is the 2015 MPLCS and the 2015 Use Table, Table 9, SUT document respectively. (Capital, Activities)...MMK58,160 billion

\footnotetext{
${ }^{2}$ The Central Statistical Organization (CSO) of the Ministry of Planning and Finance of Myanmar can authorize use of the final disaggregated SAM data upon request.
} 
Gross operating surplus. Available from the 2015 Use Table, Table 9, SUT document. The dimensions of disaggregation are 5 types of capital x 43 activities. We discuss the disaggregation in the following types of capital: agriculture capital, non-agriculture capital, land, livestock, and fishery stock in Section $7 \mathrm{~d}-\mathrm{e}$. (Act Tax, Activities)...MMK1,738 billion

Taxes on production. Available from the 2015 Use Table, Table 9, SUT document. The dimensions of disaggregation are 1 tax type $\mathrm{x} 43$ activities. The source of the disaggregation is the 2015 Use Table, Table 9, SUT document. (Activities, Commodities)...MMK177,192 billion

Domestics supply. Available from the 2015 Supply Table, Table 8, SUT document. The dimensions of disaggregation are 43 activities $\mathrm{x} 43$ commodities. The source of the disaggregation is the 2015 Supply Table, Table 8, SUT document. (Sales Tax, Commodities)...MMK1,965 billion Sales taxes. Available from the 2015 Supply Table, Table 8, SUT document. The dimensions of disaggregation are 4 tax types (excise tax, commercial tax, state lottery and transportation tax, and goods and services tax) x 43 commodities. The source of the disaggregation is the 2015 Supply Table, Table 8, SUT document. (Imp Tax, Commodities)...MMK372 billion Custom Duties. Available from the 2015 Supply Table, Table 8, SUT document. The dimensions of disaggregation are 1 tax type $\mathrm{x} 43$ commodities. The source of the disaggregation is the 2015 Supply Table, Table 8, SUT document. (Rest of the world, Commodities)...MMK14,921 billion

Imports. Available from the 2015 Supply Table, Table 8, SUT document. The dimensions of disaggregation are 1 foreign region type $\mathrm{x} 43$ commodities. The source of the disaggregation is the 2015 Supply Table, Table 8, SUT document. (Households, Labour)...MMK17,624 billion Household income from wage earnings. Calculated as a residual. The dimensions of disaggregation are 20 household types (5 quintiles, urban/rural and farm/non-farm) x 24 labour types. The source of the disaggregation is the 2015 MPLCS. (Rest of the world, Labour)...MMK0 billion Wage earnings paid to foreign (non-resident) workers. Available from the SUT document, Table 7. The dimensions of disaggregation are 24 labour types. The disaggregation reflects the shares for total domestic labour. See previous point.

11 (Enterprises, Capital)...MMK43,799 billion Enterprise income from capital. The dimensions of disaggregation are 1 type of enterprise x 5 types of capital. See Section $7 \mathrm{~d}-\mathrm{e}$ for further detail.

12 (Households, Capital)...MMK9,748 billion Household income from mixed income source. The dimensions of disaggregation are 20 household types x 5 capital types. See Section $7 d-e$ for further detail.

13 (Fact Tax, Capital)...MMK1,488 billion Taxes on the use of state properties. Available from the Statistical Yearbook 2017 (Table 17.02, p. 542). The dimensions of disaggregation are 1 tax type $x 5$ types of capital. The source of the disaggregation reflects detail available in the Statistical Yearbook 2017 (Table 17.02, p. 542).

14 (Rest of the world, Capital)...MMK3,183 billion

Payments to the rest of the world for surpluses generated by ownership of capital. Available from the SUT document, Table 7 (item D.4, property income). The dimensions of disaggregation are 5 types of capital. We allocate the full amount to non-agriculture. (Households, Enterprises)...MMK33,813 billion 
Calculated as the residual of the enterprise account. The dimensions of disaggregation are 20 household types. See Section 7d-e for further detail.

(Government, Enterprises)...MMK608 billion

Government earnings from state economic enterprises and interest receipts. Available from the Statistical Yearbook 2017, Government Budget Statistics (Table 17.02, p. 542). (Dir Tax, Enterprises)...MMK205 billion

Corporate Tax, Myanmar Business Survey (CSO 2016: Table 14).

Retained earnings by enterprises. Calculated as the balancing item of the savingsinvestment account.

(Rest of the world, Enterprises)...MMK498 billion

Payments by enterprises to the rest of the world. 60 per cent of miscellaneous current transfers (remittances). Available from the SUT document, Table 7 (item D.75). The remaining 40 per cent allocated to households. See 23 below.

(Commodities, Households)...MMK43,477 billion

Household expenditure. Available from the 2015 Use Table, Table 9, SUT document. The dimensions of disaggregation are 43 commodities x 20 household types. The source of the disaggregation is the 2015 Use Table, Table 9, SUT document and the 2015 MPLCS. (Dir Tax, Households)...MMK2,030 billion

Individual Income Tax. Taxes on Income and Profit is available from the Statistical Yearbook 2017, Government Budget Statistics, Table 17.02, p. 542. Corporate tax, see 17 above, subtracted. The dimensions of disaggregation are 20 household types. The disaggregation reflects shares from the 2012 Viet Nam SAM (Hoai et al. 2016). (Sav=Inv, Households)...MMK19,188 billion

Household savings. Calculated as the balancing item of the household accounts. Disaggregation reflects household expenditure shares.

23 (Rest of the world, Households)...MMK332 billion Payments by households to the rest of the world. 40 per cent of miscellaneous current transfers (remittances). Available from the SUT document, Table 7 (item D.75). The remaining 60 per cent allocated to enterprises_-see 19 above. The dimensions of disaggregation are 20 household types. The source of the disaggregation is the 2015 MPLCS.

24 (Commodities, Government)...MMK5,189 billion

Government expenditure. Available from the 2015 Use Table, Table 9, SUT document. The dimensions of disaggregation are 43 commodities. The source of the disaggregation is the 2015 Use Table, Table 9, SUT document.

25 (Enterprises, Government)...MMK736 billion

Interest Payments. Available from the Statistical Yearbook 2017, Government Budget Statistics (Table 17.01, p. 537).

26 (Households, Government)...MMK874 billion Social Benefit and State Pension Transfers from Government to Households. Calculated as the balancing item of the government accounts (see Section $7 \mathrm{~b}$ for more detail) The dimensions of disaggregation are 20 household types. The source of the disaggregation is the 2015 MPLCS.

27 (Sav=Inv, Government)...MMK1,919 billion

Surplus on the current account of the government. Available from the Statistical Yearbook 2017, Government Budget Statistics (Table 17.01, p. 37). 
Payments by government to the rest of the world. Available from the SUT document, Table 7 (item D.74, current international cooperation).

(Government, Act Tax)...MMK1,738 billion

Transfer from the Internal Revenue Department to government. See 4 above.

30 (Government, Sales Tax)...MMK1,965 billion

Transfer of from Internal Revenue Department to government. See 6 above.

31 (Government, Imp Tax)...MMK372 billion

Transfer of from Internal Revenue Department to government. See 7 above.

(Government, Fact Tax)...MMK1,488 billion

Transfer of from Internal Revenue Department to government. See 17 above.

33 (Government, Dir Tax)...MMK2,235 billion

Transfer of from Internal Revenue Department to government. See 21 above.

(Commodities, Sav=Inv)...MMK31,390 billion

Investment demand. Available from the 2015 Use Table, Table 9, SUT document. The

dimensions of disaggregation are 43 commodities. The source of the disaggregation is the 2015 Use Table, Table 9, SUT document.

35 (Change in stocks, $\mathrm{Sav}=\mathrm{Inv})$...MMK1,028 billion

Total of changes in stocks transferred to the savings = investment account. See 36 below.

36 (Commodities, Change in stocks)...MMK1,028 billion

Change in stocks. Available from the 2015 Use Table, Table 9, SUT document. The

dimensions of disaggregation are 43 commodities. The source of the disaggregation is the 2015 Use Table, Table 9, SUT document.

37 (Commodities, Rest of the world)...MMK13,558 billion

Exports. Available from the 2015 Use Table, Table 9, SUT document. The dimensions of disaggregation are 43 commodities. The source of the disaggregation is the 2015 Use Table, Table 9, SUT document.

38 (Labour, Rest of the world)...MMK138 billion

Transfer receipts by labour from abroad. Available from the SUT document, Table 7 (item D.1, compensation of employees). The dimensions of disaggregation is 24 labour types.

The disaggregation reflects the same shares as for total domestic labour.

39 (Capital, Rest of the world)...MMK59 billion

Transfer receipts by capital from abroad. Available from the SUT document, Table 7 (item D.4, property income).

40 (Enterprises, Rest of the world)...MMK330 billion

Transfer receipts by enterprises from abroad. Available from the SUT document, Table 7

(10 per cent of item D.75, miscellaneous current transfers, remittances).

41 (Households, Rest of the world)...MMK2,968 billion

Transfer receipts by households from abroad. Available from the SUT document, Table 7 (90 per cent of item D.75, miscellaneous current transfers, remittances). The dimensions of disaggregation are 20 household types. The source of the disaggregation is the 2015 MPLCS.

42 (Government, Rest of the world)...MMK312 billion

Transfer receipts by government from abroad. Available from the SUT document, Table 7 (item D.74, current international cooperation).

43 (Sav=Inv, Rest of the world)...MMK1,569 billion

Foreign savings $=$ deficit on the current account of the Balance of Payment. Available from the SUT document, Table 7 (item B.12 current external balance). 
Table 2: A 2015 Macro SAM for Myanmar (billions of Kyat, MMKbillion)

\begin{tabular}{|c|c|c|c|c|c|c|c|c|c|c|c|c|c|c|c|c|c|}
\hline & Row \# & Activities & Commodities & Labour & Capital & Enterprises & Households & Government & Act tax & Sales tax & Imp tax & Fact tax & Dir tax & Sav $=$ Inv & $\begin{array}{l}\text { Change } \\
\text { in stocks }\end{array}$ & $\begin{array}{c}\text { Rest of } \\
\text { the } \\
\text { world }\end{array}$ & Total \\
\hline Column \# & & 01 & 02 & 03 & 04 & 05 & 06 & 07 & 08 & 09 & 10 & 11 & 12 & 13 & 14 & 15 & 16 \\
\hline Activities & 01 & & 177,192 & & & & & & & & & & & & & & 177,192 \\
\hline Commodities & 02 & 99,809 & & & & & 43,477 & 5,189 & & & & & & 31,390 & 1,028 & 13,558 & 194,450 \\
\hline Labour & 03 & 17,486 & & & & & & & & & & & & & & 138 & 17,624 \\
\hline Capital & 04 & 58,160 & & & & & & & & & & & & & & 59 & 58,218 \\
\hline Enterprises & 05 & & & & 43,799 & & & 736 & & & & & & & & 330 & 44,865 \\
\hline Households & 06 & & & 17,624 & 9,748 & 33,813 & & 874 & & & & & & & & 2,968 & 65,027 \\
\hline Government & 07 & & & & & 608 & & & 1,738 & 1,965 & 372 & 1,488 & 2,235 & & & 312 & 8,718 \\
\hline Act tax & 08 & 1,738 & & & & & & & & & & & & & & & 1,738 \\
\hline Sales tax & 09 & & 1,965 & & & & & & & & & & & & & & 1,965 \\
\hline Imp tax & 10 & & 372 & & & & & & & & & & & & & & 372 \\
\hline Fact tax & 11 & & & & 1,488 & & & & & & & & & & & & 1,488 \\
\hline Dir tax & 12 & & & & & 205 & 2,030 & & & & & & & & & & 2,235 \\
\hline $\operatorname{Sav}=\mathbf{I n v}$ & 13 & & & & & 9,742 & 19,188 & 1,919 & & & & & & & & 1,569 & 32,418 \\
\hline Change in stocks & 14 & & & & & & & & & & & & & 1,028 & & & 1,028 \\
\hline Rest of the world & 15 & & 14,921 & & 3,183 & 498 & 332 & & & & & & & & & & 18,934 \\
\hline Total & 16 & 177,192 & 194,450 & 17,624 & 58,218 & 44,865 & 65,027 & 8,718 & 1,738 & 1,965 & 372 & 1,488 & 2,235 & 32,418 & 1,028 & 18,934 & \\
\hline
\end{tabular}

Source: Authors' calculations. 
Finalizing the SAM takes place in two stages. First, we construct a detailed SAM that contains aggregate entries for the factors of production capital and labour and for households. Up to this point, the SAM is labelled here as the SUTSAM. As mentioned at the start of the previous section, the core data of this SUTSAM comes from the SUT document's Supply and Use Table. The SUT document also provides National Accounts and the Balance of Payment statistics. In addition, we added Government Budget Statistics from CSO’s 2017 Statistical Yearbook. To complete the SUTSAM, we eliminated minor rounding errors in the SUT by means of manual adjustments.

In a second stage, we disaggregate the SUTSAM across factors and households using 2014/15 Household Survey data from the 2015 MPLCS (MoPF 2017). For wage earnings across labour types, the mapping of activities from the MPLCS to the SAM is available in Appendix C.

Next, we integrate household income and expenditure survey data and tax payments with the SUTSAM. All sources of household income and household expenditure were initially, and where possible, disaggregated across household types using the 2014/15 Household Survey data from the MPLCS. Some household expenditures are not included in the MPLCS. We use proxies from some other expenditures as shown in Appendix D. Payment of taxes and savings by individuals in households are not available in the MPLCS. We use distributions from the 2012 Viet Nam SAM (Hoai et al. 2016) for the former, while we distributed total savings across the households according to total household outlays.

The MPLCS does not record non-wage receipts by households except for social transfers from the government and those received from the rest of the world. We distributed other non-wage household income derived from capital and from enterprises across households using matching information from a 2012 Vietnam SAM (Hoai et al. 2016). We compared the resulting total income with the total outlays of each household and bi-proportional scaling of the income distribution submatrix of the SAM to balance the household accounts such that imbalances disappear while holding all other non-household-related entries of the SUTSAM constant.

\section{$5 \quad$ Employment}

We used the MPLCS to extract wage earnings. We can use the same source to estimate employment by activity and education attainment, but some additional complications are noted. A worker may have multiple jobs and it is possible to use weights based on the earnings shares of a job in a worker's total income. However, in that way we match only the non-zero incomes with non-zero counts of workers and avoid employment where there are no earnings. Yet, there may be jobs with zero income reported. That is not a problem if there is at least one job with non-zero income. Accordingly, if a worker has two jobs, but one of them has zero income reported, then the job with non-zero income gets a weight of one, as it is 100 per cent of the worker's total wage earnings. However, there are also some cases where all jobs reported zero income. If a worker has three jobs with zero income reported, they all get a zero weight. In that case, the worker do not count and total employment will be under-reported. Therefore, we scaled the results to total employment (count of workers with zero and non-zero earnings) for each labour category.

In a second step, the distribution of employment estimates across the labour types for the 13 activities of the MPLCS are applied to the 43 SAM activities using the same shares as wage earnings using the mappings shown in Appendix C. 
Finally, we scaled the employment estimates bi-proportionally to be consistent with the following benchmarks:

- Total employment according to the 2017 Statistical Year Book

- 2015 Labour Force Survey (LFS, Department of Labour, 2016, p45) reports estimates of employment shares for a limited number of broad industries

- Employment shares for urban and rural areas based on employment to population ratios from the 2015 LFS (Department of Labour, 2016. P35) and unpublished population estimates from population projections by the Department of Population.

\section{The structure of the Myanmar economy}

While SAMs are typically put together to serve as the underlying data framework of an economywide model, they can also be used as a descriptive tool to derive observations about the structure of an economy. In this section, we examine selected aspects of the Myanmar economy through the lens of the Pre-Prototype 2015 SAM. These observations are by no means exhaustive. They are a precursor for further work in this area. In this section, we consider industry value added, trade, household expenditure, and income distribution in turn.

In Table 3, we show the contribution by each of the 43 activities identified in the SAM to gross domestic product (GDP) at factor costs (i.e. excluding activity taxes). Note that aggregation has an impact on the shares, hence the high share of wholesale and retail trade. The same applies to the second (other crops) to the fourth (other manufacturing) entry in the table. Unsurprisingly, those activities feature highly in this ranking.

At the same time, specific activities such as paddy and fisheries also rank in the top ten. Agriculture is therefore an important activity in the Myanmar economy, as can be seen in the second tableau of the table showing 1-digit industry shares. Here, agriculture is second to private services only, while manufacturing comes a distant third. Back in the first tableau, it is clear that food processing contributes most to manufacturing, followed by an aggregation of unspecified other manufacturing activities. 
Table 3: Contribution to GDP at factor costs according to a 2015 SAM for Myanmar

\begin{tabular}{|c|c|}
\hline & Share in total VA@fct cst \\
\hline 1Wholesale and retail trade & $17.0 \%$ \\
\hline 2Other crops & $9.4 \%$ \\
\hline 3Food, beverage and tobacco products & $8.0 \%$ \\
\hline 4Other manufacturing products & $7.8 \%$ \\
\hline 5Construction & $6.9 \%$ \\
\hline 6Fuel minerals & $6.6 \%$ \\
\hline 7Land transport & $4.6 \%$ \\
\hline 8Fisheries & $4.5 \%$ \\
\hline 9Paddy & $4.4 \%$ \\
\hline 10Livestock & $3.5 \%$ \\
\hline 11Public admin. and defence; compulsory social security & $3.2 \%$ \\
\hline 12Restaurants & $3.2 \%$ \\
\hline 13Other services & $2.9 \%$ \\
\hline 140wner occupied dwellings & $2.3 \%$ \\
\hline 15Fruits & $1.6 \%$ \\
\hline 16Water transport & $1.6 \%$ \\
\hline 17Wearing apparel \& textiles & $1.2 \%$ \\
\hline 18Electricity, gas and steam & $1.2 \%$ \\
\hline 19Other mining including support services & $1.0 \%$ \\
\hline 20Banking & $1.0 \%$ \\
\hline 21Maintenance \& repair of motor vehicles & $1.0 \%$ \\
\hline 22Warehousing and support activities for transportation & $0.9 \%$ \\
\hline 23Vegetables & $0.9 \%$ \\
\hline 24Forestry and logging & $0.8 \%$ \\
\hline 25Health & $0.6 \%$ \\
\hline 26Other administrative and support services & $0.6 \%$ \\
\hline 27Education & $0.5 \%$ \\
\hline 28Non-metallic mineral products & $0.5 \%$ \\
\hline 29Professional, scientific and technical activities & $0.3 \%$ \\
\hline 30Domestic services & $0.3 \%$ \\
\hline 31Hotels & $0.3 \%$ \\
\hline 32Real estate & $0.3 \%$ \\
\hline 33Printing and reproduction of recorded media & $0.3 \%$ \\
\hline 34Water supply, sewerage & $0.2 \%$ \\
\hline 35Air transport & $0.2 \%$ \\
\hline 36Coke and refined petroleum products & $0.2 \%$ \\
\hline 37Computer programming, consultancy and information service activities & $0.1 \%$ \\
\hline 38Publishing, motion pictures, video, TV and radio & $0.1 \%$ \\
\hline 39Insurance and other financial auxiliary services & $0.1 \%$ \\
\hline 40Travel agencies & $0.0 \%$ \\
\hline 41 Postal and courier & $0.0 \%$ \\
\hline 42Sale of motor vehicles & $0.0 \%$ \\
\hline 43Telecommunication & $-0.3 \%$ \\
\hline Total & $100.0 \%$ \\
\hline 1Agriculture & $25.1 \%$ \\
\hline 2Mining & $7.6 \%$ \\
\hline 3Manufacturing & $18.0 \%$ \\
\hline 4Utilities & $1.4 \%$ \\
\hline 5Construction & $6.9 \%$ \\
\hline 6Private Services & $36.5 \%$ \\
\hline 7Public Services & $4.4 \%$ \\
\hline Total & $100.0 \%$ \\
\hline
\end{tabular}

Source: 2015 Myanmar SAM and authors' calculations.

Gross domestic product or value added represents payments to the factors of production capital and labour. Capital, according to the SUT document, also includes payments for mixed income, i.e. where the distinction between capital and labour is difficult to make. Tables 4 and 5 investigate what the shares are of labour and capital in GDP for the various activities identified in the Myanmar SAM. We report the top ten activities with the highest shares of labour in Table 4. 
Table 3: Wage earnings share in GDP for selected industries according to 2015 SAM for Myanmar

$\begin{array}{lr} & \text { Share in } \\ & \text { activity VA } \\ \text { Labour } \\ \text { 1Wearing apparel \& textiles } & 83.7 \% \\ \text { 2Water transport } & 63.3 \% \\ \text { 3Other administrative and support services } & 60.8 \% \\ \text { 4Public admin. and defence; compulsory social security } & 59.8 \% \\ \text { 5Postal and courier } & 53.2 \% \\ \text { 6Education } & 48.2 \% \\ \text { 7Travel agencies } & 43.0 \% \\ \text { 8Printing and reproduction of recorded media } & 42.9 \% \\ \text { 9Publishing, motion pictures, video, TV and radio } & 39.5 \% \\ \text { 10Other manufacturing products } & 36.5 \% \\ \text { 1Agriculture } & 17.9 \% \\ \text { 2Mining } & 3.9 \% \\ \text { 3Manufacturing } & 28.3 \% \\ \text { 4Utilities } & 5.5 \% \\ \text { 5Construction } & 29.9 \% \\ \text { 6Private Services } & 23.9 \% \\ \text { 7Public Services } & 53.8 \% \\ \text { 8Total } & 23.1 \%\end{array}$

Source: 2015 Myanmar SAM and authors' calculations.

The textile and clothing industry leads the way in terms of labour share in value added, followed by a number of services industries, including the public sector. However, even for the relatively high-ranking activity of travel agencies, printing, and publishing, where capital outlay is expected to be modest, the wage share is already well below 50 per cent. This suggests that there may be a significant number of owner-operated production units operating in these activities, where mixed income may be an important source of income.

The second tableau of Table 4 highlights the relatively low share of wage earnings by employed labour in GDP. The last row reports that the economy-wide average is not more than just over 23 per cent. This suggests that the mixed income or own-account earnings, which is accounted for by the production factor capital, could be an important albeit somewhat hidden component of GDP. The matching shares of capital/mixed income are available in Table 5.

Table 4: Gross operating surplus share in GDP for selected industries according to 2015 SAM for Myanmar

\begin{tabular}{lr} 
& Share in activity \\
& VA \\
Labour \\
1Telecommunication & $367.9 \%$ \\
2Owner occupied dwellings & $100.0 \%$ \\
3Domestic services & $100.0 \%$ \\
4Fisheries & $100.0 \%$ \\
5Fuel minerals & $99.0 \%$ \\
6Coke and refined petroleum products & $97.9 \%$ \\
7Electricity, gas and steam & $96.5 \%$ \\
8Livestock & $91.7 \%$ \\
9Real estate & $91.6 \%$ \\
10Insurance and other financial auxiliary services & $89.8 \%$ \\
1Agriculture & $82.1 \%$ \\
2Mining & $96.1 \%$ \\
3Manufacturing & $71.7 \%$ \\
4Utilities & $94.5 \%$ \\
5Construction & $70.1 \%$ \\
6Private Services & $76.1 \%$ \\
TPublic Services & $46.2 \%$ \\
\hline Total & $76.9 \%$
\end{tabular}

Source: 2015 Myanmar SAM and authors' calculations.

The case of telecommunication is interesting. The Use Table reports negative gross operating surplus for the industry that is larger in absolute terms than the wage earnings it pays. Hence, value 
added for the industry is negative and the share of negative gross operating surplus in negative value added then technically becomes larger than 100 per cent. We believe the reason for the negative gross operating surplus relates to high establishment investment in new segments of mobile and broadband industries so the implied losses could be of a temporary nature. A very high share is also associated with fisheries, which may be due to mainly owner-operated production units. More in line with expectations, fuel minerals, coke and refined petroleum products producers, and electricity, gas and steam are highly capital intensive, while owner occupied dwellings, domestic services, livestock, and real estate services may also have a significant degree of owner operation.

Next, we turn our attention to commodities, starting with household expenditure patterns. In Table 6, we show patterns for all households, rural households, and urban households in the respective tableaus. Expenditure of food and beverage constitutes the highest share, on average, but it is higher for rural compared to urban households. In urban areas, owner occupied dwellings, usually referring to imputed own accommodation rents is the second highest, while, as expected, it does not feature in the top ten of rural households, nor for that matter does expenditure on banking and health services. However, the opposite is the case for a number of agricultural products such as vegetables and forestry products. 


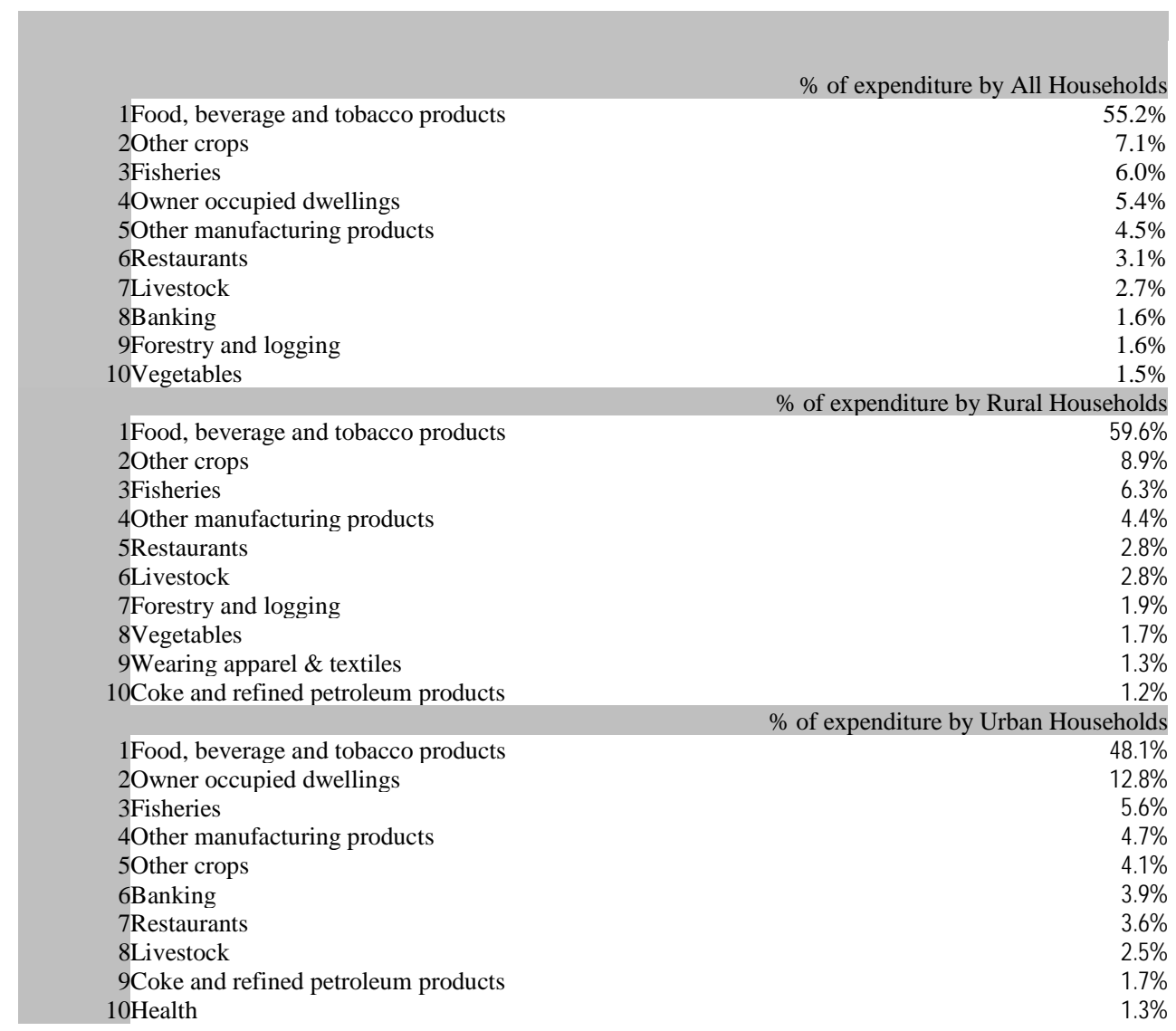

Source: 2015 Myanmar SAM and authors' calculations.

In Table 7, we show detail of commodity imports. Other manufacturing products account for more than half of total imports followed by refined petroleum and food products.

Table 6: Share in total imports and imports as a share of total supply

\begin{tabular}{lr} 
& $\%$ of total imports \\
1Other manufacturing products & $54.4 \%$ \\
2Coke and refined petroleum products & $16.9 \%$ \\
3Food, beverage and tobacco products & $8.5 \%$ \\
4Water transport & $7.0 \%$ \\
5Wearing apparel \& textiles & $3.2 \%$ \\
6Non-metallic mineral products & $2.8 \%$ \\
7Insurance and other financial auxiliary services & $2.3 \%$ \\
8Other administrative and support services & $1.0 \%$ \\
9Computer programming, consultancy and information service activities & $0.9 \%$ \\
10Other crops & $0.7 \%$ \\
1Insurance and other financial auxiliary services & Import \% of total supply \\
2Coke and refined petroleum products & $87.1 \%$ \\
3Computer programming, consultancy and information service activities & $69.0 \%$ \\
4Travel agencies & $56.6 \%$ \\
5Water transport & $44.5 \%$ \\
6Postal and courier & $34.8 \%$ \\
7Professional, scientific and technical activities & $23.8 \%$ \\
8Other manufacturing products & $20.9 \%$ \\
9Other administrative and support services & $16.4 \%$ \\
10Non-metallic mineral products & $14.0 \%$ \\
\hline
\end{tabular}

Source: 2015 Myanmar SAM and authors' calculations.

Some services, such as insurance and other financial auxiliary services and computer programming, consultancy and information service activities, and others are also in the top ten of the first tableau. 
Others such as travel agencies, water transport, postal and courier, professional, scientific and technical activities, and other administrative and support services do not account for a large share of total imports. However, import penetration-measured here by the share of these imports in total supply of these services and shown in the second tableau-is relatively high for all mentioned. In view of this, one could argue that the Myanmar economy is under-serviced by local providers.

In Table 8, data are available for exports in the same way as in Table 7 for imports. The first tableau shows the top ten shares in total exports and the second tableau shows the export-output ratio. Interestingly, fuel minerals accounts for the highest share of exports, while refined petroleum products accounts for one of the highest import shares and import penetration ratios (see Table 7). A similar picture emerges for other manufacturing products and to a lesser degree for insurance and other financial auxiliary services, wearing apparel and textiles, and food, beverage and tobacco products. This could be the result of high aggregation, where many different types of commodities and services are lumped together and the presence of 'intra-industry' trade is more likely. Nevertheless, one could also argue that this suggests that there may be opportunities for local value addition. Note also that tourism related services such as restaurants, air transport, professional, scientific and technical activities, hotels, and travel agencies display a high export share of their total output. With the gradual opening up of the country to foreign visitors, these industries are likely to gain more prominence in total exports.

Table 7: Share in total exports and exports as a share of total demand

$\begin{array}{lr} & \text { of total exports } \\ \text { 1Fuel minerals } & 39.6 \% \\ \text { 2Restaurants } & 13.0 \% \\ \text { 3Other manufacturing products } & 11.6 \% \\ \text { 4Wearing apparel \& textiles } & 8.2 \% \\ \text { 5Other crops } & 7.3 \% \\ \text { 6Fisheries } & 4.9 \% \\ \text { 7Food, beverage and tobacco products } & 3.9 \% \\ \text { 8Non-metallic mineral products } & 2.1 \% \\ \text { 9Insurance and other financial auxiliary services } & 2.0 \% \\ \text { 10Water transport } & 1.5 \% \\ \text { 1Insurance and other financial auxiliary services } & \% \text { of total demand } \\ \text { 2Fuel minerals } & 69.8 \% \\ \text { 3Publishing, motion pictures, video, TV and radio } & 55.3 \% \\ \text { 4Restaurants } & 43.8 \% \\ \text { 5Air transport } & 39.5 \% \\ \text { 6Professional, scientific and technical activities } & 28.3 \% \\ \text { 7Hotels } & 26.9 \% \\ \text { 8Travel agencies } & 25.4 \% \\ \text { 9Postal and courier } & 23.4 \% \\ \text { 10Other administrative and support services } & 22.7 \% \\ & 16.2 \%\end{array}$

Source: 2015 Myanmar SAM and authors' calculations.

Finally, we turn to the distribution of income. The sources of income for households are included in Table 9. Across the top of the table, we aggregate up to low and high income for a combination of rural/urban and farm/non-farm households. In the table, low income accounts for the first four quintiles of the SAM and high income represents the fifth quintile. The data originate from the MPLCS (MoPF 2017). Sources of income are included as row headings. Low skilled labour represents all labour except workers with tertiary education (diplomas and degrees). We divide gross operating surplus that can be associated with capital stock between agriculture and nonagriculture. We transfer the former directly to households as mixed income. We assume that nonagriculture capital transfers in full to enterprises. Hence, row 4 is empty. Enterprises then distribute that income to households as shown in row 8. Other forms of gross operating surplus transfers are associated with fish stock, land and livestock. More detail about the underlying data is available in Section $7 \mathrm{~d}-\mathrm{e}$. 
Table 8: Income distribution

\begin{tabular}{|c|c|c|c|c|c|c|c|c|c|c|}
\hline & Income sources & $\begin{array}{r}\text { Rural } \\
\text { farm } \\
\text { low } \\
\text { inc HH }\end{array}$ & $\begin{array}{r}\text { Rural } \\
\text { farm } \\
\text { high } \\
\text { inc HH }\end{array}$ & $\begin{array}{r}\text { Rural } \\
\text { non-farm } \\
\text { low } \\
\text { inc HH }\end{array}$ & $\begin{array}{r}\text { Rural } \\
\text { non-farm } \\
\text { high } \\
\text { inc HH }\end{array}$ & $\begin{array}{r}\text { Urban } \\
\text { farm } \\
\text { low } \\
\text { inc HH }\end{array}$ & $\begin{array}{r}\text { Urban } \\
\text { farm } \\
\text { high } \\
\text { inc HH }\end{array}$ & $\begin{array}{r}\text { Urban } \\
\text { non-farm } \\
\text { low } \\
\text { inc HH }\end{array}$ & $\begin{array}{r}\text { Urban } \\
\text { non-farm } \\
\text { high } \\
\text { inc HH }\end{array}$ & Average \\
\hline 1 & Low skilled labour & $10.4 \%$ & $5.8 \%$ & $39.4 \%$ & $9.4 \%$ & $8.7 \%$ & $15.9 \%$ & $60.3 \%$ & $15.1 \%$ & $18.9 \%$ \\
\hline 2 & High skilled labour & $0.4 \%$ & $0.8 \%$ & $1.5 \%$ & $0.9 \%$ & $1.3 \%$ & $5.4 \%$ & $11.6 \%$ & $13.6 \%$ & $6.0 \%$ \\
\hline 3 & Agr capital & $14.0 \%$ & $15.7 \%$ & & & $13.5 \%$ & $15.8 \%$ & & & $4.4 \%$ \\
\hline 4 & Non-agr capital & & & & & & & & & \\
\hline 5 & Fish stock & $6.8 \%$ & $19.9 \%$ & & & $0.7 \%$ & & & & $3.9 \%$ \\
\hline 7 & Livestock & $9.7 \%$ & $9.8 \%$ & & & $6.4 \%$ & $6.9 \%$ & & & $2.8 \%$ \\
\hline 8 & Enterprises & $9.7 \%$ & $13.7 \%$ & $38.7 \%$ & $84.3 \%$ & $21.8 \%$ & $22.5 \%$ & $25.1 \%$ & $69.5 \%$ & $47.7 \%$ \\
\hline 9 & Govt transfers & $0.4 \%$ & $0.3 \%$ & $4.3 \%$ & $0.8 \%$ & $0.9 \%$ & $0.2 \%$ & $1.3 \%$ & $0.7 \%$ & $1.2 \%$ \\
\hline \multirow[t]{2}{*}{10} & RoW transfers & $1.0 \%$ & $1.5 \%$ & $16.0 \%$ & $4.6 \%$ & $0.9 \%$ & $1.8 \%$ & $1.8 \%$ & $1.1 \%$ & $4.2 \%$ \\
\hline & Total & $100.0 \%$ & $100.0 \%$ & $100.0 \%$ & $100.0 \%$ & $100.0 \%$ & $100.0 \%$ & $100.0 \%$ & $100.0 \%$ & $100.0 \%$ \\
\hline
\end{tabular}

Source: 2015 Myanmar SAM and authors' calculations.

Across all households, the share of income derived from enterprises dominates, at almost 50 per cent, followed by labour at just over half that share. Most household labour earnings derive from low skilled labour. Households who are involved in farming activities, however, derive a substantial share of their income from transfers related to land, fish, and livestock and less from enterprises. Farm-based households also get a lower share of their income from labour. What they derive from agricultural capital is similar in rural areas compared to households from urban areas. Urban and non-farm households appear to receive a larger share of their income from government transfers. Rural non-farm households' share in income received from abroad is the highest, followed by urban households involved mainly in non-farm activities.

\section{$7 \quad$ Data issues}

While the SAM construction described above is a constructive first step, given the data sources at hand, we highlight a number of data issues and assumptions. They include the following points.

a. The breakdown of secondary income received from and transferred to the rest of the world between enterprises and households is not available from the Balance of Payment data. We therefore needed to make assumptions as described in the text.

b. While this is not normally our first choice, government's current income and expenditure is squared by taking the current account deficit as given by the Government Budget Statistics' difference between its current receipts and expenditures and by making government transfers to households for pensions and other social benefits (including cash transfers to students, among others) the residual.

c. The shares of land in gross operating surplus generated in production of crops, livestock and fish stock is not readily available for Myanmar. We use shares that are more or less in line with those of Viet Nam (Hoai et al. 2016).

d. We allocate the returns on non-agricultural capital in full to enterprises, and we allocate the transfers associated with agricultural capital, land, livestock, and fish stock in full to households. This follows the approach used in the construction of a 2012 Vietnam SAM (Hoai et al. 2016).

e. We use the 2015 MPLCS to disaggregate wage earnings, household income distribution, and household expenditure. Three limitations to using this survey should be observed:

- The survey only allows for the identification of 12 main activities. The mapping to the 43 activities in the SAM is available in Appendix C. 
- In the household expenditure data, some expenditures are not covered. We use proxies from other expenditures as shown in Appendix D.

- There is no distribution pattern for non-wage income from sources other than government and foreign transfers. At this stage, we use matching shares from a 2012 Vietnam SAM (Hoai et al. 2016).

\section{$8 \quad$ Way forward}

We conclude by stressing that, the SAM construction described in this study is a first useful step, given the data sources at hand. Going forward, more work on improving the SAM for Myanmar is the key task. In particular, the new 2016/17 MLCS is expected to offer better coverage of the structure of wage earnings across labour types, household expenditure, and other outlays across household groups and on the structure of income distribution. Modelling application with the SAM described in this document may reveal further gaps in our knowledge.

\section{References}

Arndt, C., H.T. Jensen, and F. Tarp, F. (2000). 'Structural Characteristics of the Economy of Mozambique: A SAM-Based Analysis’. Review of Development Economics, 4(3): 292-306.

Breisinger, C., M. Thomas, and J. Thurlow (2009). Social Accounting Matrices and Multiplier Analysis: An Introduction with Exercises. Food Security in Practice Technical Guide 5. Washington, DC: International Food Policy Research Institute. Available at:

http://www.ifpri.org/sites/default/files/publications/sp5.pdf (accessed 19 March 2019).

CSO (Central Statistical Organization) (2016). 'Myanmar Business Survey 2015, Data Report'. Available at:

http://www.mm.undp.org/content/myanmar/en/home/library/democratic_governance/ MyanmarBusinessSurvey.html (accessed 19 March 2019).

CSO (Central Statistical Organization) (2017). 'Statistical Year Book, Government Budget Statistics'. Available at:

http://mmsis.gov.mm/sub_menu/statistics/fileDb.jsp?code_code=001 (accessed 19 March 2019).

Department of Labour, 2016, Report on Myanmar Labour Force Survey-2015. Available at: http://www.mol.gov.mm/en/wp-content/uploads/downloads/2017/03/LFS-EnglishReport-_17-11-2016.pdf. (accessed 19 March 2019)

Hoai, D.Thi Thu, D. van Seventer, F. Tarp, H.Cong Hoa, and T. Trung Hieu (2016). 'A 2012 Social Accounting Matrix (SAM) For Viet Nam'. Hanoi: Finance Publishing House. Available at: https://www.wider.unu.edu/publication/2012-social-accounting-matrix-sam-viet-nam (accessed 19 March 2019).

MoPF (Ministry of Planning and Finance) (2017). 'Myanmar Poverty and Living Conditions Survey (MPLCS)'. Available at: http://documents.worldbank.org/curated/en/735011513002549172/pdf/122006-

REVISED-TechnicalReportEng.pdf (accessed 19 March 2019).

MoPF (Ministry of Planning and Finance) (2016). National Accounts and Supply and Use Table 2014-15'. Unpublished Report, Compiled by R. Kolli and T.D. Myint for the Asian 
Development Bank, Southeast Asia Regional Department (SERD) and Economics and Research Department (ERD).

Pyatt, G. (1988). 'A SAM Approach to Modelling'. Journal of Policy Modelling, 10(3): 327-52.

Pyatt, G., and J. Round (1985). Social Accounting Matrices: A Basis for Planning. Washington DC: World Bank.

Tarp, F., C. Arndt, H.T. Jensen, S. Robinson, and R. Heltberg (2002). 'Facing the Development Challenge in Mozambique: An Economy-wide Perspective'. IFPRI Research Report 126. Washington, DC: IFPRI. 


\section{Appendix A: Classifications of industries and products}

\begin{tabular}{|c|c|c|}
\hline Product\Industry & Product* (CPC 2.0) & Industry (ISIC 4) \\
\hline 1 Paddy & 113 & 112 \\
\hline 2 Vegetables & 012 (except 01231, 0124), 015, 01801, 01803 & 113 \\
\hline 3 Fruits & 013,0145 to 0149 & $0121-0126$ \\
\hline 4 Other crops & 01 (all others not in 1,2,3 above), 8611 & $\begin{array}{l}\text { 011-017 (all others), 0161, 0163, } \\
\text { 0164, part of } 015\end{array}$ \\
\hline 5 Livestock & 02, 34654, 3911, 86121 & 014, 0162, 017, part of 015 \\
\hline 6 Forestry and logging & 03, 8613, 8614, & 2 \\
\hline 7 Fisheries & 04,8615 & 3 \\
\hline 8 Fuel minerals (energy) & 11 (except 11020, 11040),12 & 05,06 \\
\hline $\begin{array}{l}9 \text { Other mining including support } \\
\text { services to mining }\end{array}$ & 13 to 16,862 & $07,08,09$ \\
\hline $\begin{array}{l}10 \text { Manufacture of food, beverage and } \\
\text { tobacco products }\end{array}$ & 21 to 25 (except 2411), 881 & 42714 \\
\hline $\begin{array}{l}11 \text { Manufacture of wearing apparel \& } \\
\text { textiles }\end{array}$ & 26 to 28 (except 2831), 8821, 8822, & $13-14$ \\
\hline $\begin{array}{l}12 \text { Manufacture of printing and } \\
\text { reproduction of recorded media }\end{array}$ & 322 to $3269,328,8912$, & 18 \\
\hline $\begin{array}{l}13 \text { Manufacture of coke and refined } \\
\text { petroleum products }\end{array}$ & 11020, 11040, 33 (except 336), 3371, 8841, & 19 \\
\hline $\begin{array}{l}14 \text { Manufacture of non-metallic mineral } \\
\text { products }\end{array}$ & 3456, 37, 38704, 46932, 8853 & 23 \\
\hline 15 Other manufacturing & $\begin{array}{l}2411283129 \text { to 31, 321, 32512, 327, 336, 3371, } 34 \text { (except 3372, 3456, } \\
\text { 34654), 35, 36,38 (except 3621, 3894, 3895, 38962, 38963), } 39 \text { (except 3911), } \\
38 \text { to } 49 \text { (except 38704, 46932, 476, 478), 8711, 8712, 87149, 87152, 87154, } \\
\text { 87156, 87159, } 873 \text { (except 87332), 8823, 883, 8842, 8843, 8851, 8852, } 886 \text { to } \\
\text { 889, 892, } 893\end{array}$ & $15-172$ 0-22 2 4-33 \\
\hline 16 Electricity, gas and steam & 17, 3372, 691, 6922, 8631, 8632, 8634 & 35 \\
\hline 17 Water supply, sewerage & $18,3621,6921,6923,8633,8635,894,941$ to 944,949 , & $36-39$ \\
\hline 18 Construction & 5,87157 & $41-43$ \\
\hline 19 Sale of motor vehicles & 61-62 (sale of motor vehicles only) & 451 \\
\hline 20 Maintenance \& repair of MV & 8714, 62281 (except sale of motor vehicles), 66282 & 452 \\
\hline 21 Wholesale and retail trade & 61-62 (all other goods) & $46-47$ \\
\hline 22 Land transport & $6411,64131,64132,6421,6422,651,6601$, & 49 \\
\hline 23 Water transport & 6412, 64133, 6423, 652, 6602, & 50 \\
\hline 24 Air transport & $64134,6424,6425,653,6603$ & 51 \\
\hline $\begin{array}{l}25 \text { Warehousing and support activities } \\
\text { for transportation }\end{array}$ & 67 & 52 \\
\hline 26 Postal and courier & 68, 32690 (part), 38962 & 53 \\
\hline 27 Telecommunication & 841,842 & 55 \\
\hline 28 Hotels & 631, 632 & 56 \\
\hline 29 Restaurants & 633,634 & $58-60$ \\
\hline $\begin{array}{l}30 \text { Publishing, motion pictures, video, } \\
\text { TV and radio }\end{array}$ & $\begin{array}{l}322 \text { to } 324,32511,3252,3253,3254,3262,3263,3895,476,478,7331,7332 \text {, } \\
83143,8363,843,846,8911,961\end{array}$ & 61 \\
\hline $\begin{array}{l}31 \text { Computer programming, } \\
\text { consultancy and information service } \\
\text { activities }\end{array}$ & 8313, 83141, 83142, 8315, 8316, 844, 85991, 87332, & $62-63$ \\
\hline 32 Banking & 32610 (part), 711, 712, 717 & 64 \\
\hline $\begin{array}{l}33 \text { Insurance and other financial } \\
\text { auxiliary services }\end{array}$ & 713 to 716 & 65 and 66 \\
\hline 34 Real estate & 72 & 68 \\
\hline \multicolumn{3}{|l|}{35 Owner occupied dwellings } \\
\hline \multicolumn{3}{|l|}{$\begin{array}{l}36 \text { Professional, scientific and technical } \\
\text { activities }\end{array}$} \\
\hline $\begin{array}{l}37 \text { Other administrative and support } \\
\text { services }\end{array}$ & $731,732,7333$ to 7339,851 to 854,8591 to 8597,945 & $77-78,80-82$ \\
\hline 38 Travel agencies & 8551 to 8556 & 79 \\
\hline $\begin{array}{l}39 \text { Public admn. and defence; } \\
\text { compulsory social security }\end{array}$ & 91 & 84 \\
\hline 40 Education & 92 & 85 \\
\hline 41 Health & 93 & $86-88$ \\
\hline 42 Domestic services & 98 & 98 \\
\hline 43 Other services & 38961, 38963, 845, 8713, 87151, 87153, 87155, 872, 95, 962 to 979,99 & 90-97, 99 \\
\hline
\end{tabular}

Note: * Characteristics of products of corresponding industries.

Source: SUT document,. 
Appendix B: Global set for a 2015 SAM for Myanmar

\begin{tabular}{|c|c|c|}
\hline Labels & Codes & Codes \\
\hline Paddy & a_paddy & c_paddy \\
\hline Vegetables & a_veggy & c_veggy \\
\hline Fruits & a_fruit & c_fruit \\
\hline Other crops & a_ocrop & c_ocrop \\
\hline Livestock & a_livst & c_livst \\
\hline Forestry and logging & a_fores & c_fores \\
\hline Fisheries & a_fishy & c_fishy \\
\hline Fuel minerals & a_fuelm & c_fuelm \\
\hline Other mining including support services & a_othmn & c_othmn \\
\hline Food, beverage and tobacco products & a_fobvt & C_fobvt \\
\hline Wearing apparel \& textiles & a_txclf & c_txclf \\
\hline Printing and reproduction of recorded media & a_print & c_print \\
\hline Coke and refined petroleum products & a_petrl & c_petrl \\
\hline Non-metallic mineral products & a_nonme & c_nonme \\
\hline Other manufacturing products & a_omanf & c_omanf \\
\hline Electricity, gas and steam & a_elctr & c_elctr \\
\hline Water supply, sewerage & a_water & c_water \\
\hline Construction & a_cnstr & C_cnstr \\
\hline Sale of motor vehicles & a_mvtrd & c_mvtrd \\
\hline Maintenance \& repair of motor vehicles & a_mvrep & c_mvrep \\
\hline Wholesale and retail trade & a_trade & c_trade \\
\hline Land transport & a_ltrnp & c_ltrnp \\
\hline Water transport & a_wtrnp & c_wtrnp \\
\hline Air transport & a_atrnp & c_atrnp \\
\hline Warehousing and support activities for transportation & a_strnp & c_strnp \\
\hline Postal and courier & a_postc & c_postc \\
\hline Telecommunication & a_telco & C_telco \\
\hline Hotels & a_hotel & c_hotel \\
\hline Restaurants & a_resta & c_resta \\
\hline Publishing, motion pictures, video, TV and radio & a_pbltv & c_pbltv \\
\hline Computer programming, consultancy and information service activities & a_itsrv & C_itsrv \\
\hline Banking & a_fnsrv & C_fnsrv \\
\hline Insurance and other financial auxiliary services & a_insur & c_insur \\
\hline Real estate & a_reale & c_reale \\
\hline Owner occupied dwellings & a_ownoc & c_ownoc \\
\hline Professional, scientific and technical activities & a_prsrv & c_prsrv \\
\hline Other administrative and support services & a_oamin & c_oamin \\
\hline Travel agencies & a_travl & c_travl \\
\hline Public admn. and defence; compulsory social security & a_padmn & c_padmn \\
\hline Education & a_educa & c_educa \\
\hline Health & a_healt & c_healt \\
\hline Domestic services & a_domsv & c_domsv \\
\hline Other services & a_othsv & c_othsv \\
\hline Margin on MVs & m_mtveh & \\
\hline Trade margin & m_trade & \\
\hline Transport margin: Land & m_ltrnp & \\
\hline Transport margin: Water & m_wtrnp & \\
\hline Transport margin: Air & m_atrnp & \\
\hline Transport margin: Services & m_strnp & \\
\hline rural_noeduc_illiterate_farm & rfm_nil & \\
\hline rural_noeduc_literate_farm & rfm_nli & \\
\hline rural_monastēy_farm & rfm_mon & \\
\hline rural_primary_farm & rfm_pri & \\
\hline rural_secondary_farm & rfm_sec & \\
\hline rural_tertiary_farm & rfm_ter & \\
\hline rural_noeduc_illiterate_nonfarm & rnf_nil & \\
\hline rural_noeduc_literate_n̄onfarm & rnf_nli & \\
\hline rural_monastery_nonfarm & rnf_mon & \\
\hline rural_primary_nonfarm & rnf_pri & \\
\hline rural_secondary_nonfarm & rnf_sec & \\
\hline rural_tertiary_nonfarm & rnf_ter & \\
\hline urban_noeduc_illiterate_farm & ufm_nil & \\
\hline urban_noeduc_literate_farm & ufm_nli & \\
\hline urban_monastery_farm & ufm_mon & \\
\hline urban_primary_farm & ufm_pri & \\
\hline urban_secondary_farm & ufm_sec & \\
\hline urban_tertiary_farm & ufm_ter & \\
\hline urban_noeduc_illiterate_nonfarm & unf_nil & \\
\hline urban_noeduc_literate_nonfarm & unf_nli & \\
\hline urban_monastery_nonfarm & unf_mon & \\
\hline urban_primary_nonfarm & unf_pri & \\
\hline urban_secondary_nonfarm & unf_sec & \\
\hline
\end{tabular}




\begin{tabular}{|c|c|}
\hline urban_tertiary_nonfarm & unf_ter \\
\hline Capital agriculture & f_capag \\
\hline Capital non-agriculture & f_capna \\
\hline Land & f_landd \\
\hline Livestock & f_livst \\
\hline Fishstock & f_fsstk \\
\hline Enterprises & i_entpr \\
\hline rural_farm_quintile1 & rfa_q1 \\
\hline rural_farm_quintile2 & rfa_q2 \\
\hline rural_farm_quintile3 & rfa_q3 \\
\hline rural_farm_quintile4 & rfa_q4 \\
\hline rural_farm_quintile5 & rfa_q5 \\
\hline rural_nonfarm_quintile1 & rnf_q1 \\
\hline rural_nonfarm_quintile2 & rnf_q2 \\
\hline rural_nonfarm_quintile3 & rnf_q3 \\
\hline rural_nonfarm_quintile4 & rnf_q4 \\
\hline rural_nonfarm_quintile5 & rnf_q5 \\
\hline urban_farm_quintile1 & ufa_q1 \\
\hline urban_farm_quintile2 & ufa_q2 \\
\hline urban_farm_quintile3 & ufa_q3 \\
\hline urban_farm_quintile4 & ufa_q4 \\
\hline urban_farm_quintile5 & ufa_q5 \\
\hline urban_nonfarm_quintile1 & unf_q1 \\
\hline urban_nonfarm_quintile2 & unf_q2 \\
\hline urban_nonfarm_quintile3 & unf_q3 \\
\hline urban_nonfarm_quintile4 & unf_q4 \\
\hline urban_nonfarm_quintile5 & unf_q5 \\
\hline Government & i_gvnmt \\
\hline Act tax & t_activ \\
\hline Excise tax & t_excis \\
\hline Commercial tax & t_commc \\
\hline State lottery and trpt tax & t_lotty \\
\hline Custom duties & t_imprt \\
\hline Subsidies on products & t_subsy \\
\hline Fact tax & t_factr \\
\hline Dir tax & t_dirct \\
\hline Savings & $\operatorname{sav}=\mathrm{inv}$ \\
\hline Change in stocks & chstcks \\
\hline Rest of the world & i_roftw \\
\hline
\end{tabular}

Source: Authors' own aggregation. 
Appendix C: Mapping of activities from MPLCS to SAM

\begin{tabular}{|c|c|c|}
\hline SAM_Labels & SAM_Codes & MPLCS_Labels \\
\hline Paddy & a_paddy & Agriculture, forestry, fishing \\
\hline Vegetables & a_veggy & Agriculture, forestry, fishing \\
\hline Fruits & a_fruit & Agriculture, forestry, fishing \\
\hline Other crops & a_ocrop & Agriculture, forestry, fishing \\
\hline Livestock & a_livst & Agriculture, forestry, fishing \\
\hline Forestry and logging & a_fores & Agriculture, forestry, fishing \\
\hline Fisheries & a_fishy & Agriculture, forestry, fishing \\
\hline Fuel minerals & a_fuelm & Mining and quarrying \\
\hline Other mining including support services & a_othmn & Mining and quarrying \\
\hline Food, beverage and tobacco products & a_fobvt & Manufacturing \\
\hline Wearing apparel \& textiles & a_txclf & Manufacturing \\
\hline Printing and reproduction of recorded media & a_print & Manufacturing \\
\hline Coke and refined petroleum products & a_petrl & Manufacturing \\
\hline Non-metallic mineral products & a_nonme & Manufacturing \\
\hline Other manufacturing products & a_omanf & Manufacturing \\
\hline Electricity, gas and steam & a_elctr & Electricity, gas, water supply, waste management \\
\hline Water supply, sewerage & a_water & Electricity, gas, water supply, waste management \\
\hline Construction & a_cnstr & Construction \\
\hline Sale of motor vehicles & a_mvtrd & Wholesale and retail trade \\
\hline Maintenance \& repair of motor vehicles & a_mvrep & Wholesale and retail trade \\
\hline Wholesale and retail trade & a_trade & Wholesale and retail trade \\
\hline Land transport & a_ltrnp & Transporation and storage \\
\hline Water transport & a_wtrnp & Transporation and storage \\
\hline Air transport & a_atrnp & Transporation and storage \\
\hline Warehousing and support activities for transportation & a_strnp & Transporation and storage \\
\hline Postal and courier & a_postc & Hospitality, communication, finance, real estate \\
\hline Telecommunication & a_telco & Hospitality, communication, finance, real estate \\
\hline Hotels & a_hotel & Hospitality, communication, finance, real estate \\
\hline Restaurants & a_resta & Hospitality, communication, finance, real estate \\
\hline Publishing, motion pictures, video, TV and radio & a_pbltv & Professional/sci. Activities \\
\hline Computer programming, consultancy and information service activities & a_itsrv & Professional/sci. Activities \\
\hline Banking & a_fnsrv & Hospitality, communication, finance, real estate \\
\hline Insurance and other financial auxiliary services & a_insur & Hospitality, communication, finance, real estate \\
\hline Real estate & a_reale & Hospitality, communication, finance, real estate \\
\hline Owner occupied dwellings & a_ownoc & Hospitality, communication, finance, real estate \\
\hline Professional, scientific and technical activities & a_prsrv & Professional/sci. Activities \\
\hline Other administrative and support services & a_oamin & Administrative, public admin \\
\hline Travel agencies & a_travl & Transporation and storage \\
\hline Public admn. and defence; compulsory social security & a_padmn & Administrative, public admin \\
\hline Education & a_educa & Educ., health, social work \\
\hline Health & a_healt & Educ., health, social work \\
\hline Domestic services & a_domsv & Other (specify) \\
\hline Other services & a_othsv & Other (specify) \\
\hline
\end{tabular}

Source: Authors' own mapping. 
Appendix D: Proxies for missing MPLCS expenditure data

\begin{tabular}{ll} 
Expenditure items & Proxy \\
Forestry and logging & Average of agriculture \\
Fuel minerals & Average of agriculture \\
Other mining including support services & Average of agriculture \\
Printing and reproduction of recorded media & Telecommunication \\
Non-metallic mineral products & Construction \\
Water transport & Land transport \\
Air transport & Land transport \\
Warehousing and support activities for transportation & Land transport \\
Postal and courier & Land transport \\
Banking & Insurance and other financial auxiliary \\
Insurance and other financial auxiliary services & services \\
Other administrative and support services & Insurance and other financial auxiliary \\
Travel agencies & services \\
Public admn. and defence; compulsory social security & Other services \\
Domestic services & Other services \\
\hline
\end{tabular}

Source: Authors' own mapping. 